\title{
The CAG repeat polymorphism in the androgen receptor gene modulates body fat mass and serum concentrations of leptin and insulin in men
}

\author{
M. Zitzmann², J. Gromoll², A. von Eckardstein ${ }^{3,4,5}$, E. Nieschlag ${ }^{1,2}$ \\ ${ }^{1}$ Institute of Reproductive Medicine of the University, Münster, Germany \\ ${ }^{2}$ Institute of Reproductive Medicine, Münster, Germany \\ ${ }^{3}$ Institute of Clinical Chemistry and Laboratory Medicine, Münster, Germany \\ ${ }^{4}$ Institute of Arteriosclerosis Research of the University, Münster, Germany \\ ${ }^{5}$ Institute of Clinical Chemistry, University Hospital of Zurich, Zurich, Switzerland
}

\section{Abstract}

Aims/hypothesis. The relationship of androgens to the metabolic syndrome has not been resolved. The polymorphic number of CAG repeats within the androgen receptor gene is inversely associated with the transcriptional activity of target genes. This polymorphism might thus influence testosterone effects on body fat content and serum concentrations of leptin and insulin. The direct and indirect role of androgens within the metabolic syndrome should become clearer if this genetically determined effector is taken into account. Methods. The hypothesis was investigated in a crosssectional study involving 106 healthy $20-50$ year old males.

Results. Multiple regression models showed a positive independent correlation of the CAG repeat number with body fat content, leptin and insulin (partial $r=0.39,0.36$ and $0.28, p<0.001, p<0.001$ and $p=0.006$, respectively). Factor analysis yielded a five-dimensional model: two dimensions were influenced by the androgen receptor polymorphism, namely "body composition" which consisted of leptin, body fat mass, insulin, the number of CAG repeats (positive loadings) and physical activity (negative loading), and "lipid profile" which comprised low density lipoprotein cholesterol, cigarette smoking, triglycerides (positive loadings) as well as high density lipoprotein cholesterol and number of CAG repeats (negative loadings).

Conclusions/interpretation. A low number of CAG repeats were independently associated with protective parameters (low body fat mass and plasma insulin) as well as with adverse parameters (low high density lipoprotein cholesterol concentrations). This suggests that the pivotal role of this polymorphism in modulating androgen effects on cardiovascular risk factors is of a complex nature and implies that its clinical impact, similar to that of androgens, is dependent on exogenous cofactors. [Diabetologia (2003) 46:31-39]

Keywords Testosterone, body fat, leptin, insulin, androgen receptor, CAG repeat polymorphism.
Received: 25 April 2002 / Revised: 21 August 2002

Published online: 20 December 2002

(C) Springer-Verlag 2002

Corresponding author: E. Nieschlag, Institute of Reproductive Medicine of the University, Domagkstr. 11, 48129 Münster, Germany, E-mail: nieschl@uni-muenster.de

Abbreviations: Ar, Adrogen Receptor; BFM, body fat mass; CAG, cytosin-adenin-guanin; CAGr, CAG repeats; FFM, fat free mass; HDL, high density lipoprotein; SHBG, sex hormone binding globuline; TBW, total body water; WHR, waist-to-hip ratio.
The term "metabolic syndrome" describes a pre-diabetic and pro-atherogenic state which is characterized by overweight, impaired glucose tolerance, hyperinsulinaemia, arterial hypertension, low concentrations of high density lipoprotein (HDL) cholesterol, hypertriglyceridaemia and disturbed haemostasis $[1,2,3,4$, $5,6]$. Several cross-sectional population studies found correlations between serum concentrations of testosterone and these cardiovascular risk factors, which, however, were opposite in men and women and which are profoundly influenced by mutual interrelationships between testosterone, adipose tissue and insulin action. In men, testosterone serum concentrations were fre- 
quently found to have inverse correlations with body mass index (BMI), waist circumference, waist-hip-ratio (WHR), amount of visceral fat as well as with serum levels of leptin, insulin and free fatty acids [7, 8, $9,10,11,12,13,14,15,16,17,18,19,20,21,22]$. These markers of obesity and insulin resistance also show correlations with the cardiovascular risk factors of the metabolic syndrome $[1,12]$. Due to these complex interrelationships it is not clear to what extent mutual interactions of direct or indirect nature exist between androgens and adipose tissue, insulin sensitivity and cardiovascular risk factors. It seems that testosterone has a diminishing effect on leptin secretion while this hormone can simultaneously induce LH production in the pituitary and suppress testicular steroidogenesis [18]. Complicating this further, concentrations of sex hormone binding globulin (SHBG) are negatively related to body fat content, which is putatively mediated by insulin $[10,23,24,25]$. These fluctuations of SHBG concentrations modulate the amount of unbound, bioactive testosterone [26]. Endogenous testosterone concentrations are most likely positively associated with glucose utilization and insulin sensitivity $[8$, $9,13]$. This applies to the effects of external testosterone in hypogonadal men, as well $[14,15]$. Age, smoking habits, alcohol consumption, physical activity and nutrition habits represent further confounding variables as they more or less influence all the above named parameters and also lipid metabolism [23, 24, 25].

A genetically determined and, hence invariable, parameter with modulatory activity of testosterone target genes would represent an ideal way to assess the causal role of androgens in the metabolic syndrome and would help to distinguish between direct and indirect mechanisms. Such a gene is the androgen receptor (AR) which mediates the genomic effects of testosterone. A variable number of CAG repeats (CAGr) in exon 1 of the AR gene on the X-chromosome, which normally ranges between 9 and 35 [27, 28] encodes for a variable number of glutamine residues in the aminoterminal domain of the receptor and is inversely associated with the transcriptional activity of testosterone target genes [29,30]. As clinical consequences, the number of CAGr was shown to be inversely associated with the risk of prostate cancer [27, 28, 31, 32, 33], benign prostatic hyperplasia $[34,35]$, sperm production [36, 37], bone density [38], endothelial function and HDL-cholesterol concentrations [39] as well as depression [40]. Furthermore, abnormal expansion of the CAGr length leads to Kennedy's disease, which is accompanied by morphological hypoandrogenic traits $[41,42]$. In this study we exploited this genetic determination of androgenicity to examine the causal contribution of testosterone to the regulation of body fat, leptin and insulin within a network of confounding variables, i.e. serum concentrations of sex hormones, lifestyle, age and various components of the metabolic syndrome. The direct and indirect role of androgens within the metabolic syndrome should become clearer if the genetically determined effector of CAGr length in the AR gene is taken into account. Respective conflicting former results might be unravelled if testosterone activity within these metabolic entities is modulated to a degree by this polymorphism.

\section{Materials and methods}

Subjects. The study was approved by the Ethics Committee of the University and the State Medical Board, Münster, Germany (number 0VIINie1). Local newspaper advertisements were placed to recruit healthy male Caucasians, from 20 to 50 years old, as volunteers willing to participate in a one-term clinical study. Information concerning clinical, biochemical and genetic investigations was provided and all volunteers gave written informed consent. Subjects were all interested in obtaining the results and received reimbursement for transportation. After exclusion of men with previous androgen use, history or symptoms that indicated atherosclerosis, diabetes mellitus and arterial hypertension as well as dyslipoproteinaemia, medication of any kind, drug abuse, a possible state of androgen deficiency (total serum testosterone below $12 \mathrm{nmol} / \mathrm{l}$ or free testosterone below $250 \mathrm{pmol} / \mathrm{l}$ ), alcohol intake of more than $40 \mathrm{~g} / \mathrm{d}$, renal or hepatic illness by history, physical examination and serum/blood analysis, 110 men were eligible to participate in the study. Further to this eight men were excluded because of medication for arterial hypertension, three were excluded for use of cholesterol-lowering drugs, two were excluded for extensive alcohol consumption, one was excluded for previously diagnosed and treated Type 1 diabetes. No exclusion was necessary because of abnormal laboratory findings or a physical exam showing pathological entities of any kind. Smoking habits, alcohol consumption $(\mathrm{g} / \mathrm{d})$, body weight and height and body mass index (BMI) were recorded. Cigarette smoking was categorized as non-smoking (0), smoking less than 10 cigarettes per day (1), smoking 10 to 20 cigarettes per day (2) and more than 20 cigarettes per day (3). Physical activity was expressed as the amount of strength and/or endurance training in hours per week, resulting in an overall score of one (none) to six ( $>9$ hours/week). This information was obtained by a standardized interview (Re-testing interobserver $\mathrm{CV}$ in 18 subjects after 3 months was $8.5 \%$ ). A potential bias might be caused by including men who were interested in their body composition and health parameters (e.g. lipid profiles). Since a proportion of the men were smokers (42 out of 106), the selection of a subgroup that followed an exceptionally health-conscious lifestyle was not likely. The distribution and mean of CAG repeats is in agreement with other larger studies in Caucasians [27]. All examinations and blood sampling were carried out between 8 am and 11 am after an overnight fast including abstinence from caffeine-based drinks for $12 \mathrm{~h}$. The clinical part of the study was completed within 4 weeks during the summer. Since the amount of blood drawn was restricted to $60 \mathrm{ml}$, multiple determinants were assessed and serum was scarce, complete parameters including leptin, insulin and c-peptide concentrations were assesssed in 106 volunteers. Other results of this study have been published previously $[38,39]$.

Bioimpedance measurements. Body fat content was assessed by bioimpedance measurement using a B.I.A 2000-M multifrequency body composition analyzer (Data Input, Frankfurt/Main, Germany). A multifrequent alternating current (1, 5, 50 or $100 \mathrm{kHz}$, respectively) was used to eliminate variations of extracellular and intracellular water content. This method is 
more accurate than a single frequency approach [43]. The same apparatus was used throughout, following the instructions given by the manufacturer. The patients were examined in a supine position after voiding. Total body water (TBW) was calculated from the measured impedance using the following formula: TBW=height ${ }^{2} /$ impedance $\times 0.585+1.825$ [44]. Fat-free mass (FFM) was then calculated from the TBW by assuming $73.2 \%$ hydration of FFM: FFM=TBW/0.732 [45]. Body fat mass (BFM) was calculated using a two-compartment model: body weight=FFM + BFM. In our institute, the intraobserver coefficient of variation $(\mathrm{CV})$ is $2.34 \%$, the interobserver $\mathrm{CV}$ is $6.77 \%$ (based on measurements by three investigators in 15 subjects). All measurements were carried out by one investigator.

Hormones and lipids. Serum testosterone (T) concentrations were measured with ELISA (DRG Instruments, Marburg, Germany), serum concentrations of $\mathrm{LH}, \mathrm{FSH}$, prolactin, prostate specific antigen, SHBG and estradiol with highly specific time-resolved fluoroimmunoassays (Autodelfia, Freiburg, Germany). Mean intraassay $\mathrm{CV}$ were below $5 \%$, mean interassay $\mathrm{CV}$ s below $10 \%$. Concentrations of free testosterone were calculated from concentrations of SHBG and total serum testosterone according to the law of mass action, using $3.6 \times 10^{4} \mathrm{l} / \mathrm{mol}$ as the association constant of testosterone with albumin and $1 \times 10^{9} 1 / \mathrm{mol}$ with $\mathrm{SHBG}$. This method yields highly reliable values of free testosterone concentrations [26].

Serum concentrations of insulin and C-peptide were assessed by solid-phase, two-site chemoluminescent enzyme-labelled immunometric assays (Immulite Insulin/C-peptide, Diagnostic Products, Los Angeles, Calif., USA). The intra-assay coefficients of variation (CV) were $3.8 \%$ and $7.5 \%$, respectively, and the interassay CVs $4.8 \%$ and $8.4 \%$, respectively. Leptin serum concentrations were measured with a radioimmunassay (Mediagnost, Reutlingen, Germany), with intra-assay and interassay CVs being $5 \%$ and $7.6 \%$, respectively.

A Hitachi 917 autoanalyzer was used for the quantification of serum concentrations of triglycerides and cholesterol with enzymatic tests, of HDL cholesterol with a homogenous assay and of apoA-I and $\mathrm{Lp}(\mathrm{a})$ with (latex-enhanced) turbidimetric immunoassays (Hitachi/ Roche Diagnostics, Mannheim, Germany). Imprecision was below 5\%. LDL cholesterol was calculated using the Friedewald formula [46].

Assessment of the number of CAG repeats. This procedure followed the method previously described $[37,38]$. DNA was isolated from EDTA blood samples using the Nucleon Kit (Amersham Life Science, Freiburg, Germany). A fragment of exon 1 of the androgen receptor was amplified by polymerase chain reaction (PCR), one gel showing irregular bands was discarded. CAG number assessment was repeated twice on two separate gel runs. Discrepancies were not observed. We cloned 18 random samples and sequenced them to confirm the validity of the measurement method being used.

Statistics. All variables were checked for normal distribution by the Kolmogorov-Smirnov one-sample test for goodness-offit applying the calculated niveau of significance according to Lilliefors. When necessary, analysis was done on logarithmically transformed data.

Basal bivariate correlations between variables in question were calculated using the two-sided Pearson's test after adjustment for age. To calculate the putative influence of various controlling parameters on single entities such as body fat content, leptin, insulin, testosterone and SHBG, forward stepwise multiple regression models were computed.

To further elucidate interdependent net effects and the putative role of the androgen receptor polymorphism within this system, the multivariate statistical tool of factor analysis was

used to assess cluster structures. All variables loading with values lower than 0.35 were discarded in this analysis. A principal components analysis with orthogonal rotation (varimax) was applied. Variables used for this analysis were age, body fat content, physical activity, insulin, leptin, HDL cholesterol, LDL cholesterol, triglycerides, total testosterone, estradiol, SHBG, alcohol consumption, cigarette smoking, systolic and diastolic blood pressure and the number of CAGr.

Computations were done using the statistical software package SPSS (Chicago, IL, USA, release 10.0.7). Unless otherwise stated, results are given as means \pm standard deviation (SD) in tables and figures. Two-sided $p$-values of less than 0.05 were considered statistically significant. Levels of statistical significance are given as asterisks in figures $\left({ }^{*},{ }^{*},{ }^{* *}\right)$ and $\left(\mathrm{a},{ }^{\mathrm{b}}, \mathrm{c}\right)$ in tables representing $p$ values below $0.05,0.01,0.001$, respectively.

\section{Results}

Basal data are given in Table 1 (data which were logtransformed for further analysis are marked with \#).

Table 1. General data of the 106 subjects studied. Data are given as mean \pm standard deviation in case of gaussian distribution, otherwise as range and median. The latter ones were log-transformed for further analysis and are marked ${ }^{\mathrm{a}}$

\begin{tabular}{llc}
\hline Parameter & \multicolumn{2}{l}{ Value } \\
\hline Anthropometrical data & & \\
Age $^{\mathrm{a}}$ & years & $20-50,28$ \\
Body Mass Index (BMI) & $\mathrm{kg \times m}{ }^{-2}$ & $23.8 \pm 3.0$ \\
Body fat content & $\%$ & $21.4 \pm 5.2$ \\
Body height & $\mathrm{cm}$ & $182.3 \pm 7.2$ \\
Body weight & $\mathrm{kg}$ & $79.1 \pm 11.7$
\end{tabular}

\section{Sociometrical data}

Physical activity

Non-smokers

Smokers

Alcohol consumption ${ }^{a}$

$\begin{array}{lc}\text { Score } & 2.5 \pm 0.9 \\ & 64 \\ & 42 \\ \text { g/week } & 0-280,60\end{array}$

\section{Hormones}

Total testosterone

Free testosterone

Estradiol

SHBG

$C A G$ repeats in the $A R$ gene

(exon 1)

Range: 14-31

Insulin, leptin, c-peptide

Insulin ${ }^{\mathrm{a}}$

Leptin $^{\mathrm{a}}$

C-peptidea

\section{Lipid profiles}

Total cholesterol

LDL cholesterol

HDL cholesterol

Triglycerides

\section{Blood pressure}

RR systolic

RR diastolic $\mathrm{nmol} / \mathrm{l}$

$\mathrm{pmol} / \mathrm{l}$

$\mathrm{pmol} / \mathrm{l}$

$\mathrm{nmol} / \mathrm{l}$

$\mu \mathrm{U} / \mathrm{ml}$

$\mathrm{ng} / \mathrm{ml}$

$\mathrm{ng} / \mathrm{ml}$

2.0-29.4, 5.4

$0.5-19.8,1.95$

$0.56-2.56,0.92$
$21.2 \pm 5.7$

$467.7 \pm 128.8$

$67.2 \pm 18.1$

$34.1 \pm 12.0$

$21.74 \pm 3.14$ $\mathrm{mmol} / 1$

$\mathrm{mmol} / \mathrm{l}$

$\mathrm{mmol} / \mathrm{l}$

$\mathrm{mmol} / \mathrm{l}$
$4.68 \pm 0.95$

$2.78 \pm 0.84$

$1.47 \pm 0.32$

$1.27 \pm 0.79$ 


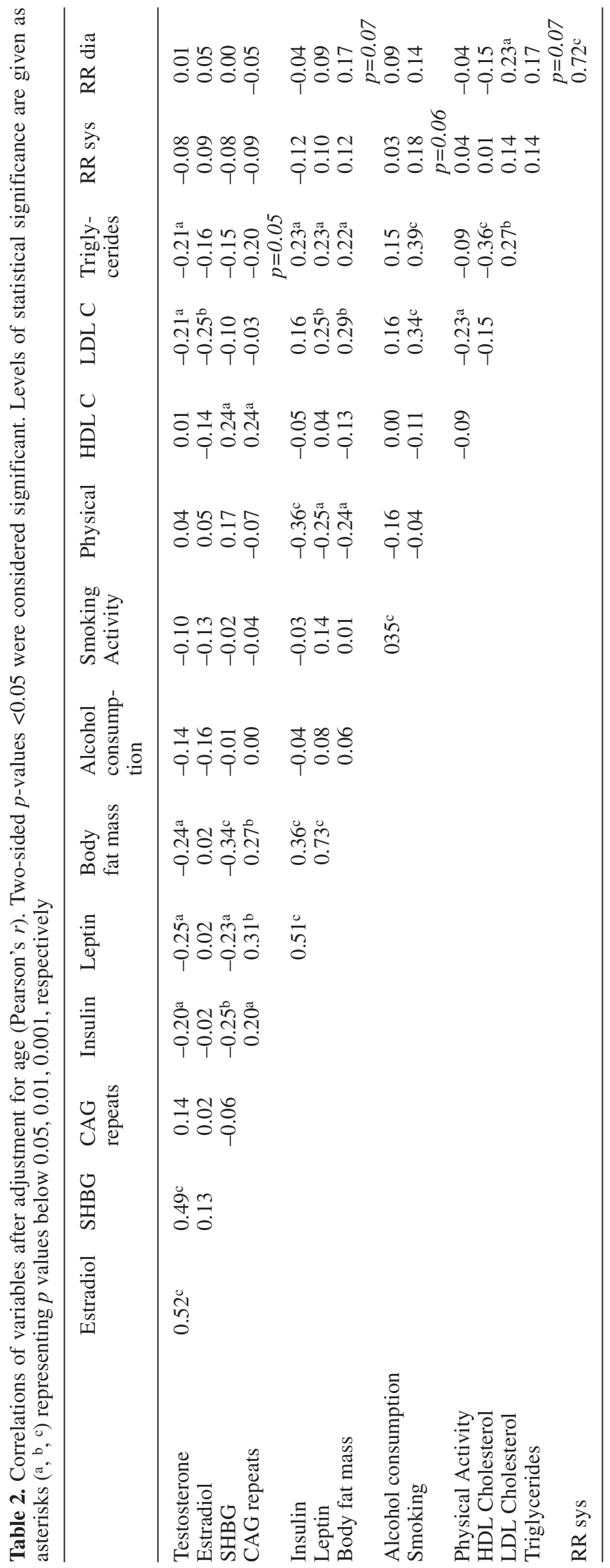




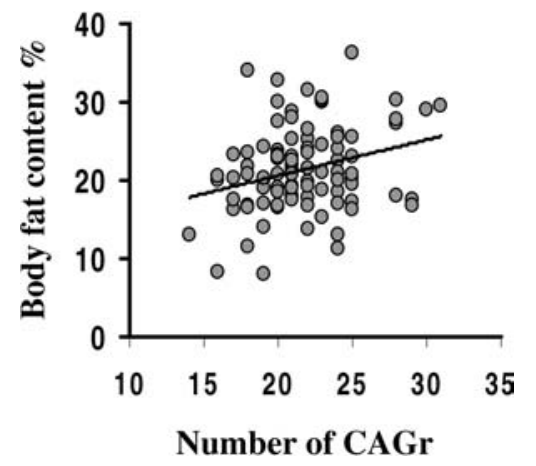

Fig. 1. Association of the length of CAG repeats in the androgen receptor gene with body fat content (adjusted for age, $r=0.27, p<0.01)$

The number of CAGr ranged from 14 to 31 and was normally distributed.

Smokers compared to non-smokers had higher concentrations of LDL cholesterol $(118 \pm 34$ vs $99 \pm 31 \mathrm{mg} / \mathrm{dl}$, $p=0.004)$ and higher concentrations of triglycerides $(139 \pm 91$ vs. $88 \pm 57 \mathrm{mg} / \mathrm{dl}, p=0.001$, both $t$-tests $)$ but did not differ otherwise. The amount of alcohol con- sumed per week was strongly associated with cigarette smoking but with no other parameters (Table 2).

There was a large inter-relation between the variables included in this investigation as shown in Table 2, which shows simple correlations after correction for age. Testosterone, SHBG and the CAGr polymorphism of the androgen receptor gene but not estradiol showed correlations with body fat content as well as with serum concentrations of insulin and leptin (Fig. 1). In addition, body fat content correlated positively with serum concentrations of insulin and leptin. Serum levels of insulin and leptin showed a high degree of inter-relation (see Table 2).

Analysing data from non-smokers only $(n=64)$ corroborated the results shown in Table 2. Despite the lower number of subjects, correlations were stronger for CAG repeats with leptin $(r=0.36, p=0.004)$, insulin $(r=0.25, p=0.04)$, triglyceride concentrations $(r=-0.24$, $p=0.05)$ and HDL cholesterol $(r=0.35, p=0.004)$. The association of the AR polymorphism with body fat content remained $(r=0.25, p=0.04)$. Such observations could also be made for correlations between testosterone, insulin and leptin.

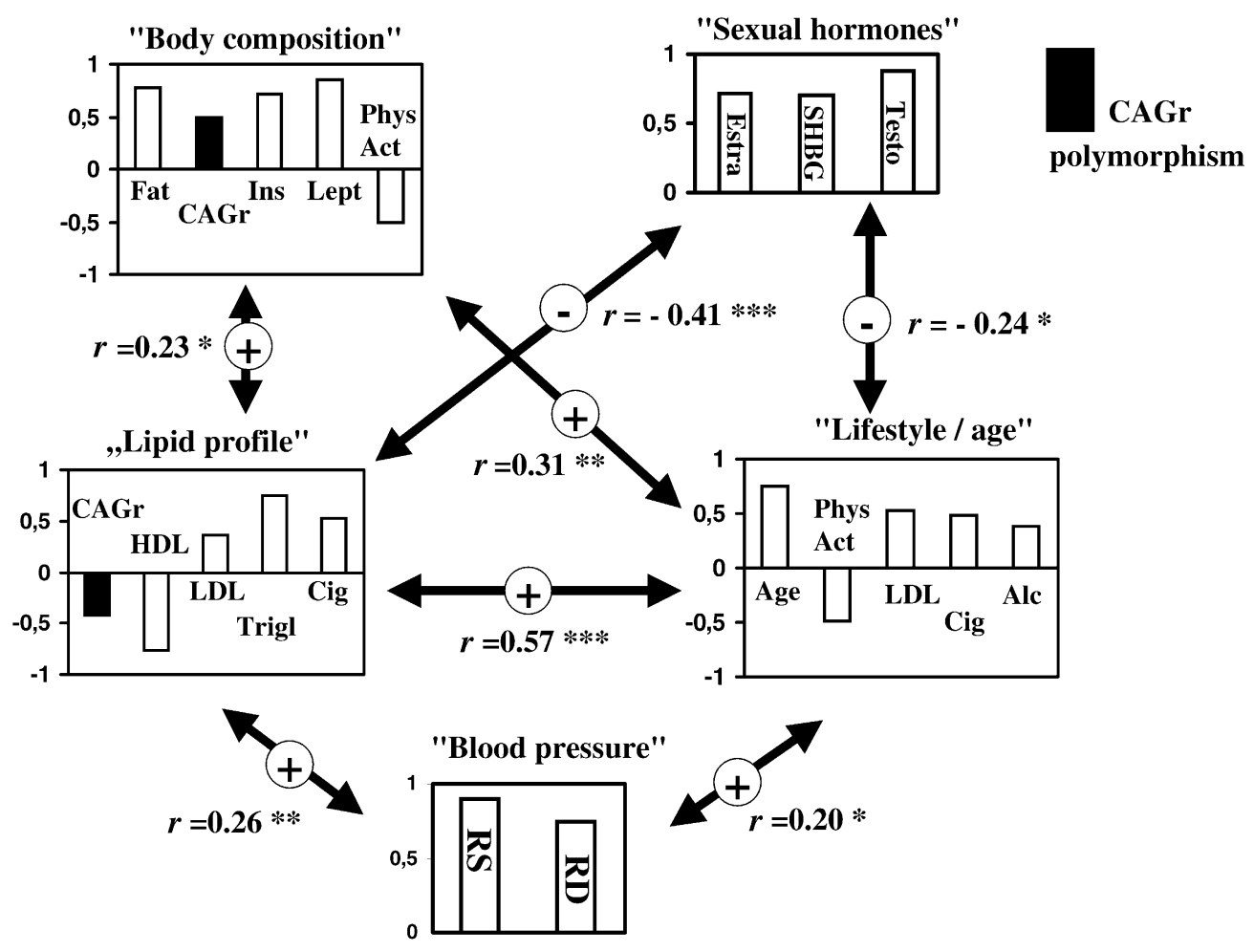

Fig. 2. The 5-factor result as determined by principal component factor analysis (varimax). Factors are shown as rectangles with their respective name above. Components loading with absolute values higher than 0.35 are shown within the factors as bars. The respective loading strength of each component can be seen from the scale ranging from -1 to 1 at the side of each factor. The CAGr polymorphism is shown as a solid bar, other components as open bars. Significant correlations between factors are shown by arrows (Pearsons $r$ is given along with level

of significance: $* p<0.05$, $* * p<0.01, * * * p<0.001)$. Abbreviations: Age age, Alc amount of alcohol consumption, Cig cigarette consumption, Estra estradiol concentrations, Fat body fat content, $H D L$ HDL cholesterol levels, Ins fasting insulin levels, LDL LDL cholesterol levels, Lept leptin levels, PhysAct Physical activity score, $R D$ diastolic blood pressure, $R S$ systolic blood pressure, $S H B G$ sex hormone binding globulin levels, Testo testosterone concentrations, Trigl triglyceride levels 
Multiple regression analysis unravelled the number of CAGr as an independent positive predictor of body fat content even after inclusion of BMI as the strongest determinant. Other independent predictors of body fat content were serum concentrations of total testosterone and physical activity (both negative). This model explained $54 \%$ of all variance in body fat content. Leptin serum concentrations were predicted by a model which included the CAGr number, BMI, insulin and alcohol consumption (all were positive predictors, $54 \%$ of all variance explained). The CAGr number was also independently and positively associated with fasting insulin serum concentrations. BMI was another positive predictor, whereas physical activity was negatively associated with fasting insulin concentrations (26\% of the variation of insulin concentrations explained).

The matrix of variables was adequate for factor analysis according to the Bartlett test as well as the measure of sampling adequacy (measure 0.75: "mediocre to meritorious"). Factor analysis yielded a fivedimensional model (Fig. 2) which explained $65 \%$ of the variance of the data included. The CAGr polymorphism of the androgen receptor gene loaded highly in two factors which are summarized by the terms body composition (positive loading) and lipid profile (negative loading). (Factor 1) Body composition, loaded positively with body fat content, leptin, insulin and the number of CAGr, it loaded negatively with physical activity. (Factor 2) Lipid profile, loaded positively with LDL cholesterol, triglycerides and cigarette smoking and negatively with HDL cholesterol and the length of CAGr. (for a display of factor loadings and their interdependencies see Fig. 2).

Factor analysis in non-smokers $(n=64)$ only yielded a similar five-dimensional model. Unlike the model shown in Fig. 2 loading of triglycerides (positive) and number CAG repeats (negative) was also found in the factor blood pressure. Alcohol consumption changed from loading in lifestyle/age to lipid profile.

Replacement of insulin by C-peptide did not improve any model, probably due to the higher $\mathrm{CV}$ of the assay, and is therefore not reported here.

\section{Discussion}

AR variants with a high number of CAGr have a lower transcriptional activity of target genes than AR variants with shorter CAGr $[29,30]$. In this study we demonstrate that this CAGr polymorphism modulates androgen effects on body fat content, insulin and leptin and thereby on cardiovascular risk factors.

Body fat content. The mutual influence between testosterone and body fat content or body mass index has been shown repeatedly. Serum testosterone is decreased in obese men and increases upon weight re- duction, hypogonadal men have higher body fat content than age-matched eugonadal men [24] which decreases upon testosterone substitution [48], probably by re-distributing body fat and reducing fat cell size [49]. To date, the underlying regulatory pathways are speculative and the modulatory effect of the CAGr polymorphism in the AR gene implies direct genomic effects of testosterone on adipocytes.

Leptin. The relationships between testosterone and leptin are also mutual as leptin exerts two antagonistic regulatory effects on sex steroid production: it induces GnRH pulsatility and thereby enhances LH (and FSH) secretion but also inhibits steroid production in Leydig cells [18]. Leptin concentrations are increased in hypogonadal men $[17,21,22]$ and can be restored to normal by testosterone substitution [21, 22]. Testosterone was also shown to inhibit leptin mRNA expression and leptin secretion by adipose tissue [18]. The modulatory effect of the CAGr polymorphism in the AR gene further emphasizes the direct androgen impact and could partly explain interindividual variations in leptin.

Insulin. Insulin and leptin are closely related hormones: an increase of insulin concentrations induces leptin secretion, but only over a longer period; thus it remains speculative whether the effect is exerted via an increment of fat tissue [49]. Leptin also increases insulin sensitivity and decreases insulin release from pancreatic beta cells by several pathways [18]. Although testosterone lowers leptin concentrations, it seems to have a beneficial effect on glucose utilization, at least in males $[13,14,15]$. This negative association is modulated by the androgen receptor gene polymorphism, an effect that, according to the regression model, cannot be completely explained by an increased amount of fat tissue fostering insulin resistance.

Metabolic syndrome and factor analysis. The co-incidence of metabolic risk factors for both Type 2 diabetes and atherosclerosis is referred to as the insulin resistance syndrome. This pre-diabetic and pro-atherogenic disorder is frequently associated with increased serum concentrations of leptin and low serum concentrations of testosterone.

Within factor models, leptin has a pathogenic role in the development of insulin resistance [1, 2, 3, 4, 5]. Usually BMI and serum concentrations of leptin and insulin form a distinct factor, as do lipid concentrations and blood pressure. We confirmed these patterns but also extended the components body composition and lipids by including the CAGr polymorphism and added the component sex hormones. Also parameters which are not directly associated (such as CAG repeats and cigarette smoking) might nevertheless contribute simultaneously to a superordinate factor (in 
this case lipid profile). The core message of this model can be described as the mutual dependency of body composition and lipids which is facilitated by leptin and insulin as well as modulated by sex hormones, the androgen receptor polymorphism and life-style. We did not include men with pathologically altered parameters contributing to the metabolic syndrome. However, the associations observed within the normal range provide good evidence that this newly gained information can be extended to clinically relevant dimensions (which have not been defined strictly).

Relevance. The significance of our findings has to be judged in the light of the conflicting knowledge concerning testosterone and cardiovascular risk factors suggesting several roles of androgens of both direct and indirect nature. Low testosterone concentrations could have an adverse effect on body composition [7, $8,9,10,51]$ and haemostatic parameters, such as plasminogen-activator-inhibitor type 1 [52, 53]. In men, low concentrations of endogenous testosterone were found to be associated with reduced concentrations of HDL cholesterol while exogenous androgens, including testosterone, decrease HDL cholesterol [8, $11,25,54,55,56]$. Low HDL cholesterol concentrations are considered unfavorable [57]. Most results on the role played by testosterone on vascular endothelium demonstrate a negative influence on functionality but are partly conflicting $[58,59,60,61,62,63,64$, 6566].

The CAGr polymorphism in the AR gene modulates testosterone effects within the body composition/insulin/leptin secretion-complex. By its attenuating influence on androgenicity, a high number of CAGr exerts adverse effects on fat mass and insulin sensitivity and thereby also on cardiovascular risk. Simultaneously, however, testosterone and a low number of CAGr in the AR gene decrease HDL-cholesterol via direct effects on pivotal genes of HDL metabolism as well as on endothelium-dependent and independent vasoreactivity [39]. Therefore, similar to testosterone, the $\mathrm{CAGr}$ polymorphism in the $\mathrm{AR}$ gene seems to play an ambiguous role in the determination of atheroclerotic risk. It probably modulates cardiovascular risk factors both adversely and beneficially.

The CAG repeat androgen receptor polymorphism modulates testosterone effects on components of the metabolic syndrome. Adverse or beneficial effects of a longer or shorter CAG repeat chain depend strongly on co-factors.

Acknowledgements. The project was supported by a grant from "Interdisziplinäres Zentrum für klinische Forschung (IZKF) Münster" (Project A3) and the "Deutsche Forschungs-Gemeinschaft (DFG) Confocal Research Group: The Male Gamete: Production, Maturation, Function”. The authors would like to thank N. Terwort and G. Klapdor for excellent technical assistance and S. Nieschlag, M.A. for language editing of the manuscript.

\section{References}

1. Lindblad U, Langer RD, Wingard DL, Thomas RG, Barrett-Connor EL (2001) Metabolic syndrome and ischemic heart disease in elderly men and women. Am J Epidemiol 153:481-489

2. Meigs JB, D'Agostino RB Sr, Wilson PW, Cupples LA, Nathan DM, Singer DE (1997) Risk variable clustering in the insulin resistance syndrome. The Framingham Offspring Study. Diabetes 46:1594-1600

3. Sakkinen PA, Wahl P, Cushman M, Lewis MR, Tracy RP (2000) Clustering of procoagulation, inflammation, and fibrinolysis variables with metabolic factors in insulin resistance syndrome. Am J Epidemiol 152:897-907

4. Leyva F, Godsland IF, Ghatei M et al. (1998) Hyperleptinemia as a component of a metabolic syndrome of cardiovascular risk. Arterioscler Thromb Vasc Biol 18:928-933

5. Hodge AM, Boyko EJ, Courten M et al. (2001) Leptin and other components of the Metabolic Syndrome in Mauritiusa factor analysis. Int J Obes Relat Metab Disord 25:126131

6. Maison P, Byrne CD, Hales CN, Day NE, Wareham NJ (2001) Do different dimensions of the metabolic syndrome change together over time? Evidence supporting obesity as the central feature. Diabetes Care 24:1758-1763

7. Barrett-Connor E, Khaw KT (1988) Endogenous sex hormones and cardiovascular disease in men. A prospective population-based study. Circulation 78:539-545

8. Simon D, Charles MA, Nahoul K et al. (1997) Association between plasma total testosterone and cardiovascular risk factors in healthy adult men: the Telecom Study. J Clin Endocrinol Metab 82:682-685

9. Stellato RK, Feldman HA, Hamdy O, Horton ES, McKinlay JB (2000) Testosterone, sex hormone-binding globulin, and the development of type 2 diabetes in middle-aged men: prospective results from the Massachusetts male aging study. Diabetes Care 23:490-494

10. Tibblin G, Adlerberth A, Lindstedt G, Bjorntorp P (1996) The pituitary-gonadal axis and health in elderly men: a study of men born in 1913. Diabetes 45:1605-1609

11. Khaw KT, Barrett-Connor E (1992) Lower endogenous androgens predict central adiposity in men. Ann Epidemiol 2:675-682

12. Marin P, Arver S (1998) Androgens and abdominal obesity. Baillieres Clin Endocrinol Metab 12:441-451

13. Oh JY, Barrett-Connor E, Wedick NM, Wingard DL (2002) Endogenous sex hormones and the development of type 2 diabetes in older men and women: the rancho bernardo study. Diabetes Care 25:55-60

14. Marin P, Krotkiewski M, Bjorntorp P (1992) Androgen treatment of middle-aged, obese men: effects on metabolism, muscle and adipose tissues. Eur J Med 1:329-336

15. Hadigan C, Corcoran C, Stanley T, Piecuch S, Klibanski A, Grinspoon S (2000) Fasting hyperinsulinaemia in human immunodeficiency virus-infected men: relationship to body composition, gonadal function, and protease inhibitor use. J Clin Endocrinol Metab 85:35-41

16. Falkner B, Sherif K, Kushner H (2000) Gender differences in the relationship between insulin-mediated glucose utilization and sex hormones in young African-Americans. J Gend Specif Med 3:60-65

17. Behre HM, Simoni M, Nieschlag E (1997) Strong association between serum levels of leptin and testosterone in men. Clin Endocrinol (Oxf) 47:237-240

18. Wauters M, Considine RV, Van Gaal LF (2000) Human leptin: from an adipocyte hormone to an endocrine mediator. Eur J Endocrinol 143:293-311 
19. Büchter D, Behre HM, Kliesch S et al. (1999) Effects of testosterone suppression in young men by the gonadotropin releasing hormone antagonist cetrorelix on plasma lipids, lipolytic enzymes, lipid transfer proteins, insulin, and leptin. Exp Clin Endocrinol Diabetes 107:522-529

20. Isidori AM, Caprio M, Strollo F et al. (1999) Leptin and androgens in male obesity: evidence for leptin contribution to reduced androgen levels. J Clin Endocrinol Metab 84:3673-3680

21. Jockenhövel F, Blum WF, Vogel E et al. (1997) Testosterone substitution normalizes elevated serum leptin levels in hypogonadal men. J Clin Endocrinol Metab 82:2510-2513

22. Hislop MS, Ratanjee BD, Soule SG, Marais AD (1999) Effects of anabolic-androgenic steroid use or gonadal testosterone suppression on serum leptin concentration in men. Eur J Endocrinol 141:40-46

23. Vermeulen A, Kaufman JM, Giagulli VA (1996) Influence of some biological indexes on sex hormone-binding globulin and androgen levels in aging or obese males. J Clin Endocrinol Metab 81:1821-1826

24. Vermeulen A, Goemaere S, Kaufman JM (1999) Testosterone, body composition and aging. J Endocrinol Invest 22:110-116

25. Gyllenborg J, Rasmussen SL, Borch-Johnsen K, Heitmann BL, Skakkebaek NE, Juul A (2001) Cardiovascular risk factors in men: the role of gonadal steroids and sex hormone-binding globulin. Metabolism 50:882-888

26. Vermeulen A, Verdonck L, Kaufman JM (1999) A critical evaluation of simple methods for the estimation of free testosterone in serum. J Clin Endocrinol Metab 84:36663672

27. Platz EA, Rimm EB, Willett WC, Kantoff PW, Giovannucci E (2000) Racial variation in prostate cancer incidence and in hormonal system markers among male health professionals. J Natl Cancer Inst 92:2009-2017

28. Hsing AW, Gao YT, Wu G et al. (2000) Polymorphic CAG and GGN repeat lengths in the androgen receptor gene and prostate cancer risk: a population-based case-control study in China. Cancer Res 1518:5111-5116

29. Chamberlain NL, Driver ED, Miesfeld RL (1994) The length and location of CAG trinucleotide repeats in the androgen receptor $\mathrm{N}$-terminal domain affect transactivation function. Nucleic Acids Res 11:3181-3186

30. Beilin J, Ball EM, Favaloro JM, Zajac JD (2000) Effect of the androgen receptor CAG repeat polymorphism on transcriptional activity: specificity in prostate and non-prostate cell lines. J Mol Endocrinol 25:85-96

31. Nam RK, Elhaji Y, Krahn MD et al. (2000) Significance of the CAG repeat polymorphism of the androgen receptor gene in prostate cancer progression. J Urol 164:567-572

32. Xue W, Irvine RA, Yu MC, Ross RK, Coetzee GA, Ingles SA (2000) Susceptibility to prostate cancer: interaction between genotypes at the androgen receptor and prostate-specific antigen loci. Cancer Res. 60:839-841

33. Modugno F, Weissfeld JL, Trump DL et al. (2001) Allelic variants of aromatase and the androgen and estrogen receptors: toward a multigenic model of prostate cancer risk. Clin Cancer Res 7:3092-3096

34. Giovannucci E, Platz EA, Stampfer MJ et al. (1999) The $\mathrm{CAG}$ repeat within the androgen receptor gene and benign prostatic hyperplasia. Urology 53:121-125

35. Mitsumori K, Terai A, Oka H et al. (1999) Androgen receptor CAG repeat length polymorphism in benign prostatic hyperplasia $(\mathrm{BPH})$ : correlation with adenoma growth Prostate 41:253-257

36. Dowsing AT, Yong EL, Clark M, McLachlan RI, de Kretser DM, Trounson AO (1999) Linkage between male infertility and trinucleotide repeat expansion in the androgen-receptor gene. Lancet 354:640-643

37. Von Eckardstein S, Syska A, Gromoll J, Kamischke A, Simoni M, Nieschlag E (2001) Inverse correlation between sperm concentration and number of androgen receptor CAG repeats in normal men. J Clin Endocrinol Metab $86: 2585-2590$

38. Zitzmann M, Brune M, Kornmann B, Gromoll J, Junker R, Nieschlag E (2001) The CAG repeat polymorphism in the androgen receptor gene affects bone density and bone metabolism in healthy males. Clin Endocrinol (Oxf) 55:649658

39. Zitzmann M, Brune M, Kornmann B et al. (2001) The CAG repeat polymorphism in the AR gene affects high density lipoprotein cholesterol and arterial vasoreactivity. J Clin Endocrinol Metab 86:4867-4873

40. Seidman SN, Araujo AB, Roose SP, McKinlay JB (2001) Testosterone concentration, androgen receptor polymorphism, and depressive symptoms in middle-aged men. Biol Psychiatry 50:371-376

41. Hsiao PW, Lin DL, Nakao R, Chang C (1999) The linkage of Kennedy's neuron disease to ARA24, the first identified androgen receptor polyglutamine region-associated coactivator. J Biol Chem 274:20229-20234

42. Mariotti C, Castellotti B, Pareyson D et al. (2000) Phenotypic manifestations associated with CAG-repeat expansion in the androgen receptor gene in male patients and heterozygous females: a clinical and molecular study of 30 families. Neuromuscul Disord 10:391-397

43 Gudivaka R, Schoeller DA, Kushner RF, Bolt MJ (1999) Single- and multifrequency models for bioelectrical impedance analysis of body water compartments. J Appl Physiol 87:1087-1096

44. Kushner RF, Schoeller DA (1986) Estimation of total body water by bioelectrical impedance analysis. Am J Clin Nutr 44:417-424

45. Pace HV, Rathbun EN (1945) Studies on body composition, body water and chemically combined nitrogen content in relation to fat content. J Biol Chem. 158:685-691

46. Friedewald WT, Levy RI, Fredrickson DS (1972) Estimation of the concentration of low density lipoprotein in plasma without use of a preparative ultracentrifuge. Clin Chem 18:449-456

47. Rummel RJ (1970) Applied factor analysis. Northwestern University press, Evanston

48. Wang C, Swedloff RS, Iranmanesh A et al. (2000) Transdermal testosterone gel improves sexual function, mood, muscle strength, and body composition parameters in hypogonadal men. Testosterone Gel Study Group. J Clin Endocrinol Metab 85:2839-2853

49. Garaulet M, Perex-Llamas F, Fuente T, Zamora S, Tebar FJ (2000) Anthropometric, computed tomography and fat cell data in an obese population: relationship with insulin, leptin, tumor necrosis factor-alpha, sex hormone-binding globulin and sex hormones. Eur J Endocrinol 143:657-666

50. Malmström R, Taskinen MR, Karonen SL, Yki-Järvinen H (1996) Insulin increases plasma leptin concentrations in normal subjects and patients with NIDDM. Diabetologia 45:1364-1366

51. Zmuda JM, Cauley JA, Kriska A, Glynn NW, Gutai JP, Kuller LH (1997) Longitudinal relation between endogenous testosterone and cardiovascular disease risk factors in middle-aged men. A 13-year follow-up of former Multiple Risk Factor Intervention Trial participants. Am J Epidemiol 146:609-617

52. Winkler UH (1996) Effects of androgens on haemostasis. Maturitas 24:147-155 
53. Zitzmann M, Junker R, Kamischke A, Nieschlag E (2002). Contraceptive steroids influence the hemostatic activation state in healthy males. J Androl 23:503-511

54. Whitsel EA, Boyko EJ, Matsumoto AM, Anawalt BD, Siscovick DS (2001) Intramuscular testosterone esters and plasma lipids in hypogonadal men: a meta-analysis. Am J Med 111:261-269

55. Singh AB, Hsia S, Alaupovic P et al. (2002) The effects of varying doses of $\mathrm{T}$ on insulin sensitivity, plasma lipids, apolipoproteins, and C-reactive protein in healthy young men. J Clin Endocrinol Metab 87:136-143

56. Büchter D, Behre HM, Kliesch S et al. (1999) Effects of testosterone suppression in young men by the gonadotropin releasing hormone antagonist cetrorelix on plasma lipids, lipolytic enzymes, lipid transfer proteins, insulin, and leptin. Exp Clin Endocrinol Diabetes 107:522-529

57. Assmann G, Schulte H, von Eckardstein A, Huang Y (1996) High-density lipoprotein cholesterol as a predictor of coronary heart disease risk. The PROCAM experience and pathophysiological implications for reverse cholesterol transport. Atherosclerosis 124:11-20

58. Herman SM, Robinson JT, McCredie RJ, Adams MR, Boyer MJ, Celermajer DS (1997) Androgen deprivation is associated with enhanced endothelium-dependent dilatation in adult men. Arterioscler Thromb Vasc Biol 17:20042009

59. Tagarakis CV, Bloch W, Hartmann G, Hollmann W, Addicks K (2000) Testosterone-propionate impairs the response of the cardiac capillary bed to exercise. Med Sci Sports Exerc 32:946-953

60. Ong PJ, Patrizi G, Chong WC, Webb CM, Hayward CS, Collins P (2000) Testosterone enhances flow-mediated brachial artery reactivity in men with coronary artery disease. Am J Cardiol 85:269-272

61. Webb CM, McNeill JG, Hayward CS, Zeigler D de, Collins P (1999) Effects of testosterone on coronary vasomotor regulation in men with coronary heart disease. Circulation 100:1690-1696

62. Thompson PD, Ahlberg AW, Moyna NM et al. (2002) Effect of intravenous testosterone on myocardial ischemia in men with coronary artery disease. Am Heart J 143:249256

63. Ebenbichler CF, Sturm W, Ganzer H et al. (2001) Flowmediated, endothelium-dependent vasodilatation is impaired in male body builders taking anabolic-androgenic steroids. Atherosclerosis 158:483-490

64. Penotti M, Sironi L, Cannata L et al. (2001) Effects of androgen supplementation of hormone replacement therapy on the vascular reactivity of cerebral arteries. Fertil Steril 76:235-240

65. Sader MA, Celermajer DS (2002) Endothelial function, vascular reactivity and gender differences in the cardiovascular system. Cardiovasc Res 15:597-604

66. Zitzmann M, Brune M, Nieschlag E (2002) Vascular reactivity in hypogonadal men is reduced by androgen substitution. J Clin Endocrinol Metab 87:5030-5037 